$\stackrel{\odot}{\text { II }}$

\title{
O MIEJSCE PRZY STOLE... PAŃSTWO WOBEC NAUK HUMANISTYCZNYCH I SPOŁECZNYCH ${ }^{1}$
}

\begin{abstract}
Jerzy Marian Brzeziński, O miejsce przy stole... Państwo wobec nauk humanistycznych i społecznych [Place at the table... the state in relation to humanities and social sciences] edited by M. Obrębska, G. Dziamski, „Człowiek i Społeczeństwo” vol. XLIX: Humanistyka jutra [Humanities of Tomorrow], Poznań 2020, pp. 175-196, Adam Mickiewicz University. ISSN 0239-3271.
\end{abstract}

The article looks at the problem of inadequacy of evaluation procedures used to assess the level of research applied by government institutions (in particular Science Evaluation Committee) to research units (institutes of Polish Academy of Sciences) and university units in relation to the actual research practice of humanities and social sciences. The author concentrates on the negative consequences for these sciences resulting from the application of the promoted model-stemming from the research practice characterising science, biological science and engineering - which consists in presenting research achievements by researchers. One of such evaluation practices distorting the real understanding of research achievements in the field of humanities and social sciences is marginalising the significance of monographs. The author takes a critical view of the new law on science and higher education introduced in 2018. New solutions which the law brought have become a source of problems concerning the accuracy of the assessment of research achievements in these disciplines. The author is particularly critical of the list of publishers imposed by the Ministry of Science and Higher Education. In his opinion this list should be abandoned. He also sees flaws in the compiled list of scientific journals. Still, despite critical remarks expressed by the academic community, the ministry has not relinquished the practice of automatic conversion of scientific achievements into points. In the author's view, an appropriate solution would be peer review - especially for humanities and social sciences (particularly for the evaluation of the scientific merit of monographs). The article contributes to the discussion on the future shape of evaluation procedure of the quality of research activity which is being prepared by the Ministry of Science and Higher Education and which will come into effect in 2022.

${ }^{1}$ Pierwsza część tytułu nawiązuje do tytułu kultowej, kilkakrotnie wznawianej książki wspomnieniowej znanego taternika i himalaisty Andrzeja Wilczkowskiego (Wilczkowski, 1982/2002): Miejsce przy stole. 
Jerzy Marian Brzeziński, Uniwersytet im. Adama Mickiewicza w Poznaniu, Wydział Psychologii i Kognitywistyki, ul. Szamarzewskiego 89, 60-568 Poznań, brzezuam@amu.edu.pl, ORCID: https://orcid. org/0000-0003-1582-4013.

\section{Wprowadzenie}

W niniejszym opracowaniu chciałbym spojrzeć całościowo na stosunek państwa do nauk humanistycznych i społecznych (dalej: NHS)². Rzecz jasna, są one elementem składowym nauki po prostu i część oddziaływań państwa na nie jest także szkodliwa dla nauki w Polsce. Jednak będę się skupiał na sytuacji NHS w naszym kraju.

Państwo, a ściślej mówiąc, jego wyspecjalizowane agendy powołane do obsługi (a można też odnieść wrażenie, że, w zamyśle urzędników państwa, mają one „właściwie” pokierować działaniami badaczy), nie rozumie (ani nie stara się zrozumieć) specyfiki „działania” NHS. Kolejne korekty ustaw, rozporządzeń i instrukcji ministerialnych nie tylko nie rozwiązują wywołanego chaosu, ale jeszcze go pogłębiają . Mało tego, powoływanie się na praktyki międzynarodowe (czytaj: państw o wyższej kulturze organizacji nauki) jest chybione, gdyż - na przykład - przeliczanie wszystkiego na punkty budzi tam raczej zdziwienie aniżeli zachwyt nad polską mądrością. Nawiasem mówiąc, dawniejsi promotorzy przeliczania osiągnięć instytucji i indywidualnych badaczy w zakresie badań naukowych na punkty dziś wypowiadają się z pogardą o tym pomyśle, nazywają go prześmiewczo

${ }^{2}$ Będę posługiwał się wygodnymi skrótami nazw grup dziedzin i dyscyplin naukowych przyjętych przez Narodowe Centrum Nauki NCN (zob. https://www.ncn.gov.pl/finansowanienauki/panele-ncn):

NHS - Nauki Humanistyczne, Społeczne i o Sztuce (tu włączono też teologię),

NŻ - Nauki o Życiu,

NŚI - Nauki Ścisłe i Inżynierskie.

W artykule skupiam się zgodnie z jego tytułem - tylko na naukach humanistycznych i społecznych. Pomijam nauki o sztuce i twórczości artystycznej - brak mi stosownych kompetencji, aby o nich sensownie pisać.

${ }^{3}$ Chciałbym zauważyć, że i minister profesor Barbara Kudrycka i minister dr Jarosław Gowin, mimo że z różnych, konkurujących ze sobą partii w równym stopniu odnieśli „sukces” na polu dekonstrukcji i szkolnictwa wyższego i zarządzania instytucjami nauki. To, co ich łączy, to nadmiar nazbyt szczegółowych regulacji, działanie prawa wstecz i promowanie - zwłaszcza w sferze organizacji szkolnictwa wyższego (także w trosce o przetrwanie, ponad rozsądną miarę rozbudowanego, sektora szkolnictwa niepublicznego) - bylejakości. 
„punktozą” i namawiają decydentów do zaniechania tej praktyki ${ }^{4}$. Niestety, machina biurokratyczna nabrała rozpędu i trudno ją teraz wyhamować. Nie zdołała tego uczynić nawet pandemia. Jest to bardzo trudne, gdyż - w miarę prosty - system przeliczania punktów dla poszczególnych jednostek naukowych i prowadzących aktywność artystyczną bardzo spodobał się urzędnikom ministerialnym, którzy mogli „obiektywnie” rozdysponować środki finansowe przeznaczone na badania naukowe i na działalność artystyczną, zaś w przypadku instytutów PAN i instytutów badawczych także na wynagrodzenia pracowników. Decydują też względy kosztowe. Według ministerstwa ocena parametryczna jest o wiele tańsza niż oceny typu peer review. Dodaje się też i taki argument, że w Polsce brak zaufania do ocen wydawanych przez ekspertów (!). Tyle - w wielkim skrócie - o genezie dziś zwalczanej i wydrwiwanej „punktozy”.

Owo całościowe spojrzenie będzie obejmowało podejście instytucji państwa nie tylko do oceny efektów instytucjonalnie prowadzonych badań naukowych (uczelnie wyższe: wydziały, instytuty, instytuty PAN, instytuty badawcze), ale też do efektów naukowych indywidualnych badaczy (wyodrębnionych w ramach grantów, awansów naukowych oraz konkursów związanych z zatrudnieniem). Wreszcie, nie sposób przemilczeć naruszeń etyki zawodowej, które - śmiem twierdzić, że na dotychczas niespotykaną skalę - występują w środowisku akademickim jako swoiste pokłosie wprowadzanych reform.

O ile ocena indywidualnych osiągnięć naukowych była systematycznie prowadzona czy to w miejscu zatrudnienia pracownika (przede wszystkim oceny okresowe i związane z awansami naukowymi), czy - dodatkowo przez centralne instytucje kontrolne (na przykład centralna ocena, a nawet zatwierdzanie wniosków habilitacyjnych i profesorskich przez specjalną komisję powoływaną przez premiera) od 1951 roku (więcej na ten temat:

${ }^{4}$ Na przykład Andrzej K. Wróblewski, (2017: 22) pisał: „Trzeba mieć nadzieję, że wkrótce także wszyscy polscy badacze przypomną sobie, iż celem badań naukowych nie jest zdobywanie punktów ministerialnych ani licytowanie się na wskaźniki bibliometryczne, lecz poszukiwanie prawdy o otaczającym nas świecie i wykorzystywanie wyników do odkrywania ich zastosowań. Trzeba także mieć nadzieję, że administratorzy nauki w Polsce uwolnią się z zauroczenia bibliometrią, wyleczą się z «impaktomanii» oraz «punktozy» i zgodzą się na metody oceny badań, jakie są stosowane w krajach i instytucjach przodujących w nauce” (wyróż. moje). Ja pod takim stanowiskiem w pełni się podpisuję. Szkoda tylko, że już tak daleko zabrnęliśmy na tej, prowadzącej na bagna, drodze. Przełamanie oporu ministerialnych biurokratów i rachmistrzów nie będzie łatwe. Próbować jednak trzeba - zwłaszcza występując w obronie NHS. 
Brzeziński, 2017; Wojtczak, 1996a, 1996b, 1997a, 1997b), to systematycznie prowadzona ocena pozycji naukowej jednostek uczelnianych (na ogół wydziały), instytutów PAN oraz instytutów badawczych ${ }^{5}$ jest prowadzona w sposób wystandaryzowany i systematycznie dopiero od połowy lat 90 . ubiegłego wieku.

Ustanowienie pakietu nowych regulacji prawnych, z dwiema nowymi ustawami o szkolnictwie wyższym i o awansach naukowych (1990 rok) na czele, dało nowy demokratyczny oddech stłamszonym ideologicznie uczelniom $^{6}$. Dało też polskiej nauce odnowioną w 1991 roku Centralną Komisję do Spraw Stopni i Tytułów (jej członkowie byli, pierwszy raz, powołani w drodze demokratycznych wyborów spośród wszystkich uczonych, którzy mieli tytuł naukowy profesora). Powstał też - co zawdzięczamy wizji i uporowi prof. Witolda Karczewskiego (1930-2008) - w 1991 roku Komitet Badań Naukowych (KBN) ${ }^{7}$; jego pierwszym przewodniczącym był Witold Karczewski (lata: 1991-1995). Tak wyglądały obiecujące początki demokratyzującego się zarządzania nauką w Polsce. Byłem członkiem pierwszego Zespołu Nauk Humanistycznych i Społecznych (przewodniczący: wybitny historyk prof. Henryk Samsonowicz) wchodzącego w skład Komisji Badań Podstawowych.

Dziś tamtego optymizmu nie podzielam. Zbyt wiele się zmieniło - na gorsze.

\section{W imadle „naukowej" biurokracji}

\section{Wprowadzenie nadmiernej standaryzacji, z naciskiem na (wyłącznie!) ilościowe ujęcie oceny, stało się poważnym problemem nierównego traktowania NHS w podejściu do rekomendowanych (przez minister- stwo i KEN) strategii ewaluacyjnych na tle pozostałych nauk. (Na temat sztuki nie wypowiadam się, gdyż podejmowane próby skwantyfikowania ocen dzieł plastycznych, muzycznych oraz teatralnych i filmowych mogą jedynie nas rozbawić albo wprowadzić ich twórców w stan zakłopotania). \\ Zgubnym dla trafnej oceny dokonań naukowych badaczy i instytucji ich zatrudniających było wyłączne skupienie się na miejscu publikacji artykułu}

${ }^{5}$ W rozumieniu Ustawy z dnia 30 kwietnia 2010 r. o instytutach badawczych (tekst jednolity z 28 czerwca 2019 r.).

${ }^{6}$ Ustawa z dnia 12 września 1990 r. o szkolnictwie wyższym; Ustawa z dnia 12 września 1990 r. o tytule naukowym i stopniach naukowych.

7 Ustawa z dnia 12 stycznia 1991 r. o utworzeniu Komitetu Badań Naukowych. 
naukowego, a nie na jego treści. Najwyżej ocenianymi czasopismami naukowymi były te, które znajdowały się na tak zwanej liście filadelfijskiej ${ }^{8}$ (obecnie jest to baza Journal Citation Reports JCR występująca w dwóch wersjach: Journal Citation Reports (JCR) Science Edition oraz Journal Citation Reports (JCR) Social Sciences Edition). Im wyższą wartość wskaźnika Impact Factor (IF) miało dane czasopismo, tym wyższą wartość punktową przypisywano opublikowanemu w nim artykułowi. A treść artykułu? A kto by sobie głowę zawracał takim „drobiazgiem”. Liczy się bowiem - w wyścigu o „godne” miejsce w rankingach - „dziedziczenie prestiżu”9: wysoki prestiż (mierzony wartością IF) tytułu czasopisma przenosi się na autora artykułu w nim opublikowanego i, w dalszej kolejności, na zatrudniającą go uczelnię czy instytut. Szczególnie zaś nieprzystawalność procedur ewaluacyjnych wypracowanych, tak naprawdę, w środowisku nauk ścisłych oraz biologicznych i medycznych do praktyki badawczej NHS dała się odczuć w traktowaniu tych ostatnich przez odpowiednie organy ministerstwa (na przykład powołana

${ }^{8}$ To polska nazwa zaproponowana przez Andrzeja K. Wróblewskiego. Obecnie ta lista wydawana jest przez firmę Clarivate Analytic. Trzeba zauważyć, że nie obejmuje ona czasopism z zakresu klasycznej humanistyki i jako taka jest nieprzydatna dla dokonywania ewaluacji artykułów naukowych powstałych w HS (jedynie czasopisma psychologiczne znajdują się na niej w dość reprezentatywnym zestawie). Próby równoległego wprowadzenia bazy SCOPUS, znacznie obszerniejszej i obejmującej też (ale zbyt mało) czasopisma o profilu HS, nie zyskał aprobaty ministerstwa.

${ }_{9}$ Zob. wnikliwy artykuł na ten temat napisany przez znawcę problematyki (Kulczycki, 2019: 7): „W Polsce od 1999 roku tworzy się wykazy czasopism punktowanych, na podstawie których ocenia się artykuły naukowe w czasopismach zawartych w tychże wykazach. Taki model oceny określa się mianem dziedziczenia prestiżu, ponieważ przyjmuje się, że artykuł wart jest tyle, ile czasopismo, w którym jest opublikowany. Jednocześnie w przypadku oceny publikacji książkowych stosuje się model zgoła odmienny, oparty na spełnianiu kryteriów formalnych przez publikacje recenzowane”. W tym modelu - nazwijmy go nieco upraszczając - „dziedziczenia prestiżu”, liczą się wyłącznie te artykuły (o monografiach, tak charakterystycznych dla klasycznych dyscyplin humanistycznych, się nie mówi), które zostały opublikowane w najważniejszych dla danej dziedziny czasopismach naukowych. Czołowy polski orędownik tego modelu uprawiania nauki Marek Kwiek w swojej wypowiedzi na łamach UAM-owskiego Życia Uniwersyteckiego (Kwiek, 2020: 15) pisał: „Podział naukowców według rangi czasopism, w których publikują, był zawsze częścią szerszego etosu nauki: konkurencja w nauce to również konkurencja o publikowanie wyników badań w najlepszym możliwym miejscu. [...] konkurencja jest żywiołem nauki (ale już niekoniecznie żywiołem szkolnictwa wyższego". Marek Kwiek, przykładowo, wymienia cztery o wysokim prestiżu czasopisma (wszystkie z NŻ i NŚI): Nature, Science, Cell, Lancet. A czasopisma z HS? Czy badacze z NHS nie tworzą nauki? Czy nie należy im się „miejsce przy stole”? 
1 marca 2019 roku na czteroletnią kadencję Komisja Ewaluacji Nauki KEN). No bo - na przykład - jak zawalczyć o „prestiż”, gdy czasopisma humanistyczne i większość społecznych (poza psychologicznymi) z najwyższej światowej półki nie występują w bazie JCR i nie mają przypisanej wartości IF? Można, oczywiście, stworzyć jakąś krajową namiastkę IF (były takie próby stworzenia Polskiego Współczynnika Wpływu, ale słuch o nich zaginął) i w jakiś wymyślny sposób przypisywać czasopismom punkty (znowu - jak wańka-wstańka - wraca, w wersji soft, punktoza). Problem jednak w tym, że nie da się w ten sposób dokonywać porównań międzynarodowych. No bo jak? Proponowane przez ministerstwo i KEN procedury - w wymiarze NHS - mają jedynie lokalny, polski charakter.

Nadal $^{10}$ - jednak w ograniczonym zakresie - podzielam pogląd Jerzego Wilkina (Wilkin, 2013: 46), że właściwa, uwzględniająca specyfikę przedmiotu badań oraz metody w poszczególnych dziedzinach czy dyscyplinach naukowych i, w konsekwencji, także języków upubliczniania efektów badań naukowych ocena bibliometryczna czasopism naukowych ma podstawowe znaczenie i dla funkcjonowania instytucji naukowych, i dla awansów naukowych poszczególnych badaczy:

Ranking punktowy czasopism naukowych, podobnie jak i parametryzacja jednostek naukowych, jest próbą obiektywizacji ich jakości i pozycji na potrzeby pragmatyki postępowania przy podziale środków finansowych na naukę. Chodzi o wypracowanie przejrzystych i obiektywnych podstaw podziału funduszy publicznych, służących finansowaniu jednostek naukowych, zespołów i projektów badawczych, a także ocenie osiągnięć naukowych, zarówno poszczególnych badaczy, jak i instytucji. Obecnie parametryzacja jednostek w dużym stopniu zależy od klasyfikacji czasopism. Z parametryzacją wiąże się kategoryzacja, za którą idą pieniądze budżetowe. Można przyjąć, że punkty przyznawane czasopismom stanowią istotną część fundamentu dobrobytu bądź przyczyn upadku jednostek naukowych. (wyróż. moje)

Trzeba jednak - w kontekście tej wypowiedzi - zwrócić uwagę na trzy, nie do pominięcia, problemy.

10 Taki sam pogląd wyrażałem w mojej poprzedniej publikacji (zob. Brzeziński, 2015: 10). Od tego czasu, po prostu, nic naprawdę ważnego dla naprawy wadliwego systemu się nie wydarzyło. Łatanie „dziur” za pomocą nowych, coraz bardziej wymyślnych „łatek” (przypominające aktualizację kulejącego systemu WINDOWS) wywołało jedynie nowe kontrowersje - na przykład skrytykowany przez środowisko naukowe wykaz „wydawnictw publikujących recenzowane monografie naukowe”, który Minister NiSzW utworzył 17 grudnia 2019 roku. 
Problem pierwszy odnosi się do konieczności odrębnego traktowania ewaluacji jednostek naukowych (wydziałów itp.) i ewaluacji pojedynczych badaczy. Narzędzia naukometryczne wypracowane dla oceny poziomu badań naukowych prowadzonych w danej jednostce nie mogą być, automatycznie, stosowane do oceny dorobku naukowego pojedynczych badaczy (stopnie naukowe i tytuł naukowy, granty, zatrudnienie). A tak, niestety, się dzieje.

Problem drugi dotyczy „obiektywizacji” ocen osiągnięć poszczególnych badaczy. Łatwo popaść w swoisty punktowy redukcjonizm: eksperci/ recenzenci nie czytają (ze zrozumieniem i odniesieniem do stanu wiedzy przedstawionej w najnowszych światowych publikacjach), a jedynie przyglądają się zebranym przez ocenianego pracownika punktom: IF, sumIF, indeks Hirscha, liczba cytowań (Brzeziński, 2015; 2016). Nie jest ważna treść artykułu, a ważne jest miejsce opublikowania artykułu i przypisana mu liczba punktów (modne „dziedziczenie prestiżu”).

Problem trzeci wiąże się z tym, że publikowanie w czasopismach naukowych nie jest tak samo priorytetowo traktowane przez badaczy reprezentujących różne grupy dyscyplin naukowych (sztukę pomijam). Dla badaczy z klasycznych dyscyplin humanistycznych publikowanie w czasopismach nie jest tak ważne jak dla badaczy z nauk ścisłych, biologicznych czy medycznych, a także dla psychologów. Z kolei badacze z nauk humanistycznych (przykładowo: historycy i literaturoznawcy) dużą wagę przypisują monografiom, gdy - przykładowo - chemicy, biolodzy, medycy czy psychologowie - traktują monografie marginalnie.

Pisaliśmy na marginesie przeprowadzonej parametryzacji za okres: 2013-2016 (Antonowicz i Brzeziński, 2017: 93):

[...] środowisko NHS (zwłaszcza dyscypliny klasycznie humanistyczne) domaga się uwzględnienia ich specyfiki. Naszym zdaniem, oczekiwania od KEJN nowych uregulowań - pisanych na kanwie doświadczeń z tej parametryzacji - nie musi oznaczać „topienia się” w zbędnych i wcale niepoprawiających jakości ewaluacji szczegółach [...]. Szukajmy prostych rozwiązań, ale szanujmy osobliwości dużych grup nauk. Pozwólmy zatem humanistom docenić monografie (co nie oznacza, że wszystko, co ma okładki, jest od razu monografią), a przedstawicielom nauk społecznych, przyrodniczych, ścisłych, technicznych itp. artykuły drukowane w dobrych czasopismach o zasięgu międzynarodowym. I niekoniecznie musi to być „uświęcona” lista filadelfijska. Prostota reguł nie musi oznaczać lekceważenia jednych przez drugich. Niestety, dziś przedstawiciele NHS mają takie poczucie krzywdy. (wyróż. moje) 
Tę ocenę trzeba - koniecznie! - wzbogacić o pogłębioną ocenę monografii naukowych. Ta - jako składowa sumarycznej oceny publikacji - ma zróżnicowane, w zależności od dziedziny nauki i dyscypliny naukowej, znaczenie. Weźmy przykład kontinuum naukowego znaczenia typu publikacji: „monografia naukowa wydana w uznanym w środowisku wydawnictwie - artykuł ogłoszony w czasopiśmie naukowym, rejestrowanym w uznanych przez środowisko międzynarodowych bazach (na przykład SCOPUS)”. Preferencje literaturoznawców (dziedzina: nauki humanistyczne) lokują się na pierwszym biegunie, zaś preferencje zdecydowanej większości psychologów (dziedzina: nauki społeczne) na drugim. Myślę, że stosunek do miejsca publikacji naukowej: artykuł wydrukowany w czasopiśmie (zwłaszcza w języku angielskim) versus monografia ogłoszona drukiem w akceptowanym przez daną dyscyplinę humanistyczną języku i wydawnictwie (i niekoniecznie jest to język angielski) jest znaczącym czynnikiem rozbijającym jednorodność grupy dyscyplin NHS. Ona tylko dla osób spoza grupy wydaje się monolitem. Tak jednak nie jest. Ten problem niejednorodności został radykalnie (nazbyt?) rozwiązany we wszystkich dziedzinach i dyscyplinach naukowych przez ministerstwo poprzez wprowadzenie nowych zasad przeprowadzenia oceny parametrycznej. Oto porównywane ze sobą będą nie jednostki organizacyjne (wydziały w uczelniach czy instytuty PAN i badawcze), ale same dyscypliny naukowe figurujące na nowej liście ministerialnej, wyjęte ze struktur organizacyjnych uczelni czy instytutów. Jaki to da efekt, zobaczymy w 2022 roku. Ale czy ten pomysł - w zmieniającej się dość dynamicznie sytuacji politycznej w kraju - zostanie wprowadzony w życie? Na to pytanie nikt dziś nie jest w stanie udzielić odpowiedzi. Nawet nowy minister. Moim zdaniem ministerstwo nie jest przygotowane do przeprowadzenia parametryzacji jednostek naukowych i zajmujących się sztuką i skwapliwie, pod pretekstem pandemicznym przesunęło całą operację o jeden rok (na 2022 rok).

Ponieważ jednak tak silny nacisk został położony i przez ministerstwo, i przez KEN/KEJN - i to niezależnie od dziedziny czy dyscypliny naukowej - na artykuły opublikowane w czasopismach naukowych, więc arcyważne staje się stworzenie trafnej dla danej dyscypliny (względnie szerzej: dla dziedziny) i intersubiektywnie akceptowalnej w środowisku NHS listy czasopism naukowych.

To powinna być lista utworzona przez zespół ekspertów, a kryteria przez nich wypracowane podlegać środowiskowej dyskusji. Tryb powołania ekspertów powinien być transparentny i uwzględniać znaczących przedstawicieli subdyscyplin składających się na daną dyscyplinę. 
Z ciekawą propozycją znoszenia wytworzonego - przez niewłaściwą praktykę ewaluacji osiągnięć naukowych jednostek naukowych prowadzoną w poprzednich czteroletnich okresach przez KEJN (szczególnie dwie poprzednie ewaluacje przeprowadzone w 2013 i 2017 roku) - wymiernych ilościowo podziałów: publikowanie w czasopismach naukowych (ostro preferowane i nagradzane stosownie wysoką punktacją) versus publikowanie monografii, monografii zbiorowych i przedziałów w monografiach zbiorowych (o takiej samej, niskiej punktacji niezależnie od ich objętości, wagi naukowej i czasu zużytkowanego na ich powstanie) wystąpił Emanuel Kulczycki (2019). W swoim, uwzględniającym także doświadczenia innych krajów, opracowaniu rozpatrzył „cztery wyzwania”:

Wyzwanie 1: Waga podstawowych kanałów publikacji naukowych:

Dotychczasowy model oceny publikacji naukowej wskazywał, że w każdej dyscyplinie naukowej najważniejszym kanałem publikacji jest czasopismo naukowe, za publikację w którym można było otrzymać większą liczbę punktów niż za publikację monografii. Takie rozwiązanie powinno zostać zastąpione modelem, w którym najlepsza monografia jest warta więcej od najlepszego artykułu opublikowanego w czasopiśmie. (s. 21)

Zgadzam się z Kulczyckim, że nie powinno to oznaczać przechylenia wahadła ewaluacyjnego w stronę maksymalnej oceny punktowej każdej monografii - niezależnie od potrzebnego na jej napisanie czasu i trudności w jej wytworzeniu. Przykładowo: monografia o objętości, powiedzmy, 5 arkuszy ${ }^{11}$ nie jest żadną miarą porównywalna z monografią kilkudziesięcioarkuszową zbierającą wyniki wieloletnich studiów, kwerend przeprowadzonych w archiwach czy technicznie złożonych empirycznie badań laboratoryjnych (na przykład psychologia eksperymentalna, neuropsychologia). I nie każdy przegląd literatury - dziś łatwo osiągalny w Internecie zasługuje na miano monografii naukowej. To zaś oznacza uwzględnienie podejścia peer review. No bo jak inaczej?!

To, że de facto różne dyscypliny NHS zostały dotychczas uznane za spójne w podejściu do wzorców publikacyjnych oznacza, że twórcy tego rozwiązania nie zadali sobie trudu wejrzenia w zróżnicowane obyczaje

${ }^{11}$ Chciałbym zauważyć, iż z definicji monografii zniknęła jej minimalna objętość (6 arkuszy). Zatem można sobie wyobrazić „syntezę introligatorską” o objętości, powiedzmy, 2 arkuszy (100 pkt.) - taki dłuższy artykuł w czasopiśmie naukowym. W „rywalizacji” $\mathrm{z}$ artykułami publikowanymi w polskich czasopismach o profilu humanistycznym plasuje się na samym topie. 
publikacyjne w poszczególnych dyscyplinach NHS. Psychologowie, przykładowo, zdecydowanie preferują publikowanie artykułów naukowych w czasopismach anglojęzycznych. I pod tym względem bliżej im do grupy NŻ. Zapewne - chociażby z tego powodu - trzeba rozbić z pozoru tylko jednorodną grupę NHS. Zaś dyscypliną naukową, która najbardziej odstaje od wzorca humanistycznego NHS, jest psychologia.

Wyzwanie 2: Model oceny monografii oparty na zasadzie dziedziczenia prestiżu:

Monografia jest fundamentalnym kanałem publikacji, ale nie jest to najpopularniejszy sposób komunikacji w dzisiejszej humanistyce (Kulczycki i in., 2018). Zwiększenie punktacji za najlepsze monografie oraz wprowadzenie listy uznanych wydawców pozwoli prawdziwie docenić jakość monografii. Punktowe dowartościowanie monografii powinno pociągnąć za sobą wdrożenie tożsamych metod oceny wszystkich kanałów publikacji poprzez uznanie funkcjonującej od ponad pół wieku w naukometrii oraz wdrożonej w systemach ewaluacji nauki m.in. w Danii, Finlandii, Norwegii i Hiszpanii - zasady dziedziczenia prestiżu (artykuł jest wart tyle, ile czasopismo, w którym jest opublikowany, a książka jest warta tyle, ile wydawnictwo ją wydające). (s. 22)

To wyzwanie zostało bardzo skutecznie zniweczone przez ministra, który stworzył „autorską” (dziś już inny minister musi się jej wstydzić! tak to jest, gdy o ważnych rozwiązaniach dla nauki decydują politycy) listę wydawców z podziałem na dwa poziomy:

Poziom II: 36 wydawców działających na skalę międzynarodową (przypisano im 200 pkt.); monografiom HS i teologii z Poziomu II przypisano 300 pkt.

Poziom I: 677 wydawców (przypisano im 80 pkt.); monografiom HS i teologii z Poziomu I przypisano 100 pkt.

Spójrzmy na rozdętą listę wydawców z poziomu I. Toż to swoiste kuriozum! Znajdują się na niej poważni naukowi wydawcy (w tym nieliczni zagraniczni) i wydawcy niszowi (też publikacji konfesyjnych), szerzej nieznani środowisku naukowemu. Zauważmy jeszcze - litościwie przyjmując tę listę za dobrą monetę - że wszyscy wydawcy (677!) z tej listy są tak samo wycenieni: 80 pkt. (a w NHS i teologii 100 pkt.). Przecież nie można na jednej płaszczyźnie zestawić Wydawnictwa Naukowego PWN, Elsevier, John Wiley \& Sons czy Wydawnictwa Naukowego Scholar z wydawnictwem małej szkoły z nazwy tylko „wyższej” (i w tym wypadku małe wcale nie jest piękne). Poważną wadą owej listy jest też jej spłaszczenie.

Ministerstwo przedstawiło „piękne” uzasadnienie dla tej listy ${ }^{12}$ :

12 Zob. https://konstytucjadlanauki.gov.pl/pierwsza-wersja-nowego-wykazuwydawnictw-juz-jest-wiekszosc-pozycji-to-wydawnictwa-polskie. 
Przedstawiciele nauk humanistycznych, społecznych i teologicznych od lat domagali się podniesienia w procesie ewaluacji rangi monografii naukowych. W ramach rozporządzenia o ewaluacji, które zostanie opublikowane w najbliższych tygodniach, liczba punktów za monografie zostanie zdecydowanie podniesiona: z 25 do 80 punktów, a w przypadku monografii humanistycznych, społecznych i teologicznych opublikowanych w wąskiej grupie 36 najważniejszych wydawnictw światowych - do 300 punktów (oraz do 200 punktów w przypadku pozostałych dziedzin).

Przywracając monografii naukowej należną jej rangę głównego kanału komunikacji treści naukowych w obrębie wspomnianych trzech dziedzin nauki, trzeba równocześnie wyeliminować - lub co najmniej znacząco ograniczyć - zjawisko przedstawiania do ewaluacji monografii o niskiej wartości naukowej lub wręcz publikacji pseudonaukowych. Temu celowi służy wykaz wydawnictw.

Jednak nie można pominąć milczeniem tego uzasadnienia. Ministerialny wykaz wydawnictw żadną miarą nie może być uznany za probierz rangi naukowej monografii. A automatyczne podniesienie punktacji (i znowu nieszczęsna punktoza) wydawnictw z I poziomu: z 25 do 100 pkt., oraz wybranych wydawnictw z II poziomu: z 200 do 300 pkt. nijak się ma do ambitnego programu eliminowania z ewaluacji „,...] monografii o niskiej wartości naukowej lub wręcz publikacji pseudonaukowych”. Nie chcę się powtarzać i przywoływać wydawców, którym daleko do trzymania wysokiego poziomu naukowego drukowanych monografii. Krytyczny Czytelnik sam sobie może wyrobić opinię na ten temat. Przecież nie o taką pomoc ministerstwa ubiegają się przedstawiciele NHS. Opublikowana lista wydawnictw skutecznie wzmacnia bylejakość.

Jeżeli już (załóżmy, przez chwilę, że tak trzeba) powstała lista, to powinna być ona niezbyt długa, licząca kilkadziesiąt starannie dobranych pozycji. Powinna też być zróżnicowana na trzy-cztery poziomy. Osobiście jednak wątpię w powstanie takiej obiektywnej listy.

Wyzwanie 3: Definicje naukowych publikacji książkowych

[...] w definiowaniu typów publikacji książkowych powinno zrezygnować się zarówno z definiowania objętości, jak i liczby autorów, a jedynie wskazywać na wymóg poddania danej publikacji recenzji naukowej. Poprzez wybranie uznanych wydawnictw naukowych, które dbają i dbać powinny o jakość publikowanych przez siebie książek, będzie się uznawało daną monografię naukową za możliwą lub nie do uwzględnienia w ewaluacji. (s. 22-23) (wyróż. moje)

To nie tak prosto. Co z tego, że monografia będzie opatrzona nazwiskiem recenzenta. W związku z tym dwa pytania. Pytanie pierwsze: jaka 
jest pozycja naukowa recenzenta i czy jest on kompetentny w przedmiocie opiniowanej monografii? I kto to oceni? To, że recenzent legitymuje się tytułem naukowym profesora czy stopniem doktora habilitowanego danej dziedziny i dyscypliny nauki, nie wystarczy. Musi się znać na problematyce opiniowanej książki. Dziś wszyscy wydawcy z listy ministerialnej poddają publikowane książki procedurze recenzenckiej. Nie stanowi to najmniejszego problemu dla nawet bardzo słabego wydawcy. Bywa i tak, że wydawca zadowala się tym, że to autor sam przynosi pakiet: tekst książki plus recenzja (oczywiście pozytywna). Zatem nie sam fakt opiniowania monografii jest ważny. Ważne jest, kto i jak sporządził recenzję.

Kulczycki pisze: „[...] wybranie uznanych wydawnictw naukowych”. Minister wybrał i co? Powinien się wstydzić, a lista powinna zniknąć. Jednak do czasu nowelizacji ustawy: Prawo o szkolnictwie wyższym i nauce ta lista będzie nas uwierała. Czy musi powstać nowa? Jeżeli tak, to musi być ona konstruowana z wielką staranności i przy podniesionej kurtynie. Nie mogą być na nią przemycane wątpliwej jakości naukowej wydawnictwa.

Wyzwanie 4: Balans między różnymi grupami nauki w ocenie czasopism [...] nowy model oceny czasopism - jeśli ma być oparty na wskaźniku bibliometrycznym - powinien być oparty na takim wskaźniku, który wyliczany jest również dla nauk humanistycznych. Spośród dwóch największych baz, w których wyliczane są wskaźniki bibliometryczne dla czasopism, tj. bazie Web of Science Core Collection oraz bazie SCOPUS, tylko w tej drugiej można znaleźć trzy wskaźniki, które są obliczane dla nauk humanistycznych. Mowa tutaj o wskaźnikach: SNIP - Source Normalised Impact per Paper; SJR SCImago Journal Rank; oraz CiteScore. Biorąc pod uwagę cel wykorzystania stworzonego na podstawie wskaźnika wykazu, najbardziej adekwatnym do tego celu jest wskaźnik SNIP, który - będąc wskaźnikiem znormalizowanym względem różnych dziedzin nauki - pozwala na wykorzystanie tego samego wskaźnika w jednym modelu dla różnych grup nauk. (s. 23)

Zgadzam się, że odpowiednią bazą jest SCOPUS i wskaźnik SNIP. Możemy też - patrząc szerzej - przyjąć kilka równolegle stosowanych międzynarodowych baz (charakterystycznych dla poszczególnych dziedzin - w tym i dla NHS) oraz dobrze wyselekcjonowaną i niewielką listę krajową (stworzoną ekspercko). I jeszcze jedno: żadną miarą nie należy uznawać bazy ERIH PLUS za narzędzie mające zastosowanie w procedurach ewaluacyjnych. Jest to bowiem jedynie baza rejestrowa. Każdy wydawca czasopisma z dyscyplin MHS może się w niej zarejestrować - wystarczy spełnić parę kryteriów formalnych. A ministerstwo wyróżnia czasopisma, które zarejestrowały się w tej bazie. 


\section{Instytucjonalizacja nauki - jak są/będą oceniane dokonania naukowe jednostek naukowych, dyscyplin naukowych i pojedynczych badaczy}

Zobaczmy zatem te miejsca, w których - na polskiej mapie organizacji nauki - dokonywana jest ewaluacja czy to jednostek naukowych (w celu przyznania im środków na funkcjonowanie ${ }^{13}$ ), czy pojedynczych badaczy (w celu ich awansowania, zatrudnienia na określonych stanowiskach zawodowych, przyznania środków na sfinansowanie grantów badawczych). Każda podejmowana przez uprawiony podmiot decyzja wymaga odwołania się do wiedzy eksperckiej odpowiednich specjalistów i zespołów ekspertów. Przyjrzyjmy się temu, jak to działa w Polsce. Pomocna będzie rycina 1.

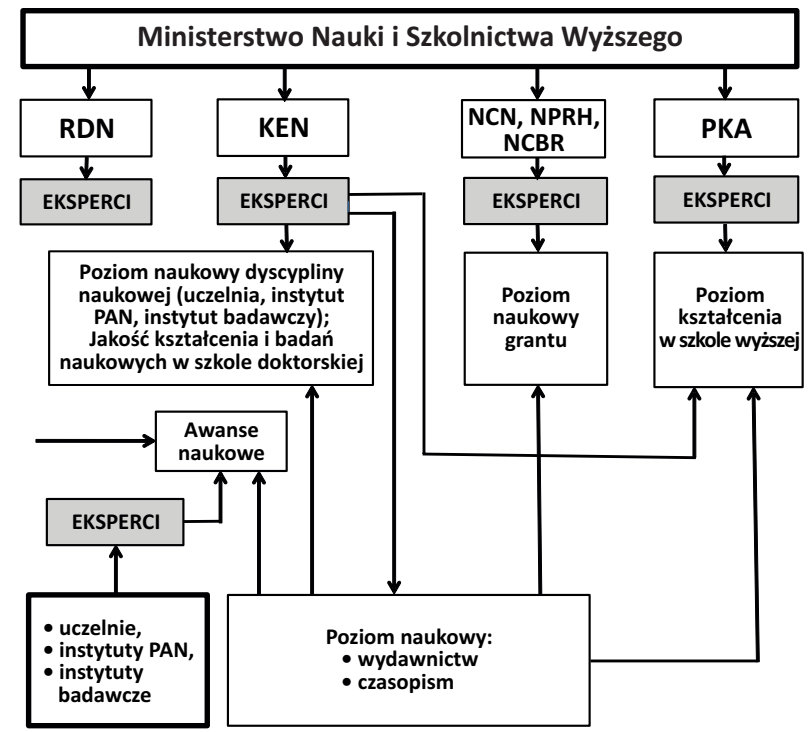

Ryc. 1. Oddziaływania instytucjonalne na jednostki naukowe oraz na osoby prowadzące badania naukowe i kształcące studentów

objaśnienia skrótów: RDN - Rada Doskonałości Naukowej, KEN - Komisja Ewaluacji Nauki, NCN - Narodowe Centrum Nauki, NPRH - Narodowy Program Rozwoju Humanistyki, NCBR - Narodowe Centrum Badań i Rozwoju, PKA - Polska Komisja Akredytacyjna

${ }^{13}$ Wbrew intencjom ustawodawcy środowisko naukowe zaczęło traktować parametryzację prestiżowo. Rektorzy i prezes PAN zaczęli się ścigać: który z nich zdobędzie więcej kategorii „A+” dla swoich jednostek. Powiązano też kategorie z uprawnieniami do prowadzenia przewodów doktorskich i habilitacyjnych. Ta „sportowa” atmosfera nie sprzyja spokojnemu prowadzeniu badań naukowych i zajęć dydaktycznych ze studentami. 
Ministerstwo oddziałuje na środowiska naukowe przede wszystkim poprzez cztery podstawowe instytucje:

1. Komisję Ewaluacji Nauki KEN (powołaną przez Ministra NiSzW w 2019 roku): do jej zadań należy (zob. https://www.gov.pl/web/ nauka/komisja-ewaluacji-nauki):

[...] przeprowadzanie ewaluacji jakości działalności naukowej, przygotowanie projektów wykazu wydawnictw publikujących recenzowane monografie naukowe oraz wykazu czasopism naukowych i recenzowanych materiałów z konferencji międzynarodowych; przedstawianie ministrowi propozycji kategorii naukowych dla podmiotów poddanych ewaluacji; sporządzanie opinii i ocen w sprawach określonych przez ministra lub z własnej inicjatywy; ewaluacja jakości kształcenia w szkole doktorskiej; sporządzanie analiz w zakresie ewaluacji jakości działalności naukowej i jakości kształcenia w szkołach doktorskich, a także współpraca z krajowymi i międzynarodowymi instytucjami zajmującymi się ewaluacją jakości działalności naukowej ${ }^{14}$. (wyróż. moje)

Okresowe przeprowadzanie, co cztery lata, ewaluacji jakości badań naukowych prowadzonych w dyscyplinach naukowych rejestrowanych w: uczelniach, instytutach PAN i instytutach badawczych. Poprzednia ocena (2017 rok) dotyczyła jednostek naukowych i przeprowadził ją Komitet Ewaluacji Jednostek Naukowych KEJN (a jeszcze wcześniej: Komitet Badań Naukowych KBN). Z powodu trwającej pandemii koronawirusa ocenę przesunięto na rok 2022;

2. Radę Doskonałości Naukowej RDN (powołaną przez Ministra NiSzW w 2018 roku). Od 1 stycznia 2021 roku zastąpi Centralną Komisję do Spraw Stopni i Tytułów. Ocena wniosków awansowych przeprowadzana jest w zespołach odpowiadających dziedzinom nauk i dziedzinie sztuki. W interesującym nas HS są to dwa zespoły: nauk humanistycznych (archeologia, filozofia, historia, językoznawstwo, literaturoznawstwo, nauki o kulturze i religii, nauki o sztuce) oraz nauk społecznych (ekonomia i finanse, geografia społeczno-ekonomiczna i gospodarka przestrzenna, nauki o bezpieczeństwie, nauki o komunikacji społecznej i mediach, nauki o polityce i administracji,

${ }^{14}$ Wymienione zadania zostały rozłożone w trzy zespoły:

1) ewaluacji jakości działalności naukowej (przewodniczący Zbigniew Kąkol, fizyk z AGH); 2) ewaluacji szkół doktorskich (przewodniczący Dominik Antonowicz, socjolog z UMK);

3) wykazów wydawnictw monografii naukowych oraz czasopism naukowych i recenzowanych materiałów z konferencji międzynarodowych (przewodniczący Emanuel Kulczycki, filozof z UAM). 
nauki o zarządzaniu i jakości, nauki prawne, nauki socjologiczne, pedagogika, prawo kanoniczne, psychologia);

3. Narodowe Centrum Nauki NCN, Narodowy Program Rozwoju Humanistyki NPRH, Narodowe Centrum Badań i Rozwoju NCBR. Są to instytucje powołane do inicjowania i obsługi grantów badawczych. Badaczy z HS interesują przede wszystkim dwie pierwsze instytucje. Z kolei NPRH adresowany jest głównie do badaczy z obszaru klasycznej humanistyki;

4. Polską Komisję Akredytacyjną PKA - jej misja obejmuje: „,... ] dbałość o spełnianie standardów jakościowych przyjętych dla szkolnictwa wyższego, nawiązujących do najlepszych wzorców obowiązujących w europejskiej i globalnej przestrzeni edukacyjnej, oraz wspieranie uczelni publicznych i niepublicznych w procesie doskonalenia jakości kształcenia a także budowania kultury jakości”.

Pomocniczymi, opiniodawczymi - dla Ministra NiSzW - organami są jeszcze Rada Główna Nauki i Szkolnictwa Wyższego oraz Komitet Polityki Naukowej.

Wymienione instytucje (poza tymi pomocniczymi) w swoich pracach ewaluacyjnych odwołują się do kompetencji ekspertów. To, co przede wszystkim oceniają, to publikacje - czy to pojedynczych badaczy (awanse naukowe, konkursy zatrudnieniowe, granty), czy to zespołów tworzących: jednostki podstawowe na uczelni (na ogół wydziały), instytuty PAN, instytuty badawcze.

W przeprowadzonej w 2017 roku Kompleksowej ewaluacji jednostek naukowych każda jednostka mogła przedstawić do oceny jedynie (chociaż dla słabych naukowo jednostek można napisać, że „aż”) „3N - 2N $\mathrm{N}_{0}$ ” publikacji ${ }^{15}$.

${ }^{15}$ Gdzie: N - średnia liczba zatrudnionych w jednostce w latach objętych ewaluacją pracowników prowadzących badania naukowe; $\mathrm{N}_{0}$ - liczba pracowników, którzy nie opublikowali żadnej pracy naukowej. Tak naprawdę to tych publikacji będzie więcej. Mam na myśli publikacje współtworzone przez badaczy z innych jednostek wspólnie z badaczem/badaczami w danej jednostce. KEN posługuje się pojęciem „slotu”. „Kilka publikacji wieloośrodkowych, czyli takich, których autorzy byli afiliowani do różnych instytucji naukowych, zapełniało jeden slot, a nie kilka - w ten sposób system pozwalał na zbalansowanie oceny praktyk publikacyjnych z różnych dziedzin, na przykład z humanistyki, gdzie przeważająca większość prac jest jednoautorska, oraz fizyki, gdzie zdarzają się również prace z kilkoma tysiącami autorów" (Kulczycki, 2019: 9). Konstrukcja slotu pozwala na praktyki nieetyczne - przez umiejętne żonglowanie pracami współautorskimi. Ci badacze, którzy publikują samodzielne prace, i to w wysoko punktowanych czasopismach, nie „przebiją” wieloautorskich slotów. O ile publikowanie prac (zwłaszcza artykułów) w psychologii (nauka społeczna) staje się prawie codziennością, to w klasycznej humanistyce nie jest to nadal zjawisko rozpowszechnione. To kolejny przykład na tylko pozorną jednorodność NHS. 
Te publikacje, to: artykuły naukowe ogłoszone drukiem w czasopismach naukowych, rozdziały w monografiach zbiorowych, monografie, monografie zbiorowe. Twórcy tych regulacji - kierując się, ich zdaniem, „słuszną” dla wszystkich dyscyplin naukowych zasadą - ograniczyli maksymalną liczbę monografii i monografii zbiorowych - w NHS było to $40 \%$ liczone w stosun-

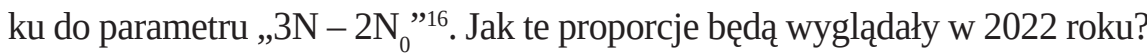
Jeżeli nie zmieni się obowiązujące rozporządzenie (Rozporzq̨dzenie Ministra Nauki i Szkolnictwa Wyższego z dnia 22 lutego 2019 roku w sprawie ewaluacji jakości działalności naukowej), to będzie to 20\% w NHS i 5\% w pozostałych dziedzinach. Pozostałe publikacje to artykuły w czasopismach i rozdziały w monografiach zbiorowych. Widać wyraźnie, że ustawodawca chce ukierunkować aktywność publikacyjną badaczy na zamieszczanie wyników badań w czasopismach. Zaś udział procentowy monografii w całym koszyku publikacyjnym znacząco ogranicza. Nie sądzę, aby badacze reprezentujący klasyczne dyscypliny humanistyczne akceptowali takie deprecjonowanie monografii. Zadajmy zatem pytanie: czy badania naukowe w obszarze NHS prowadzą uczeni, czy też ci, którzy piszą ustawy i rozporządzenia ministerialne? Nie da się podciągnąć twórczości naukowej pod jeden zalgorytmizowany wzorzec. Nie sprawdziło się wprowadzenie przed laty - dla wszystkich dyscyplin naukowych - bazy WoS (sławetna lista filadelfijska) i łaskawe (dla HNS) uzupełnienie jej bazą ERIH. Też narzucenie przez ministerstwo (zob. przypis 18) tego samego wzorca oceny publikacji w procedurze habilitacyjnej z prymarną rolą bazy WoS dla wszystkich dyscyplin naukowych budzi opór wśród badaczy z kręgu klasycznej humanistyki.

Moim zdaniem niezbędna jest zmiana definicji monografii. W obecnie obowiązującej zrezygnowano z określenia minimalnej liczby arkuszy. Poprzednio było to 6 arkuszy (i tak zbyt mało). Teraz (art. 265 ust. 9 pkt. 1) wymagane jest tylko tyle, że książka jest „,wydana przez wydawnictwo publikujące recenzowane monografie naukowe”. Z kolei Rozporzq̨dzenie Ministra Nauki i Szkolnictwa Wyższego z dnia 22 lutego 2019 roku w sprawie ewaluacji jakości działalności naukowej uzupełnia tę definicję o wymóg, że „recenzowana publikacja książkowa” powinna przedstawiać: „,...] określone zagadnienie naukowe w sposób oryginalny i twórczy” (§ 10 ust. 1 pkt. 1). Pytanie: kto ma stwierdzić, że owa monografia rzeczywiście jest i oryginalna, i twórcza? W procedurze oceny poziomu naukowego dyscyplin naukowych uprawianych w danej jednostce naukowej, która poddała się ewaluacji, nie przewidziano. Zawierzanie, że książka pochodzi z wydawnictwa z listy ministra, a tam mogły się znaleźć wydawnictwa

${ }^{16}$ W: NŻ - 10\%, NŚI - 20\%; Sztuka i twórczość artystyczna - 25\%. 
jedynie wówczas, gdy recenzowały wydawane monografie, to zdecydowanie zbyt mało. Myślę, że - jeżeli chcemy traktować poważnie całą procedurę ewaluacyjną - peer review nie unikniemy. Póki co, w projektowanych zmianach przywołanego rozporządzenia nie ma mowy o peer review.

Ogłoszony przez ministerstwo Wykaz wydawnictw publikujq̨cych recenzowane monografie naukowe pokazuje, jak słabe jest poleganie na oświadczeniu, że monografia była recenzowana. Ów wykaz wydawnictw wymaga gruntownej zmiany. Pozostawienie go w obecnym kształcie, albo tylko uzupełnianie go o kolejne pozycje, jest wysoce szkodliwe.

Także trzeba dopracować listę czasopism. Widać, że przy tworzeniu list czasopism wskazanych przez ekspertów zabrakło koordynacji pracy tych zespołów w ramach wyłonionych trzech grup: NHS, NB i NŚI. Być może wystarczą uznane bazy, takie jak na przykład baza SCOPUS. W NHS można pokusić się o stworzenie bazy eksperckiej, która powstałaby w szerokiej konsultacji ze środowiskiem humanistycznym.

\section{Wnioski}

Moim zdaniem obowiązujący - koncepcyjnie nadmiernie zawiły i prawnie niedopracowany - system ewaluacji nauki i rządowej promocji określonego „stylu” prowadzenia badań naukowych nie gwarantuje, zwłaszcza w odleglejszej perspektywie czasowej, uzyskiwania w Polsce poważnych osiągnięć naukowych i odnawiania - dobrze przygotowanych do prowadzenia badań naukowych - kadr naukowych ${ }^{17}$. Narzucony przez państwo system zniechęca

${ }^{17}$ Nawiasem mówiąc, przedstawiony do konsultacji projekt z 29 kwietnia 2020 r. rozporzqdzenia Ministra Nauki i Szkolnictwa Wyżzzego zmieniajq̨cego rozporzq̨dzenie w sprawie ewaluacji jakości działalności naukowej (mowa o rozporzq̨dzeniu z dnia 22 lutego 2019 r. w sprawie ewaluacji jakości działalności naukowej) wcale nie czyni reguł „gry parametryzacyjnej” bardziej przejrzystymi i - co równie ważne - zrozumiałymi dla przeciętnego pracownika uczelni czy instytutu; dostęp: https://legislacja.gov.pl/docs//506/12333258/12684112/12684113/dokument446341.pdf. Mało tego, i ustawa i rozporządzenie zachęcają wręcz do tego, aby źle nie wypaść w ocenie parametrycznej. Podam przykład. Możliwe jest postępowanie rektorów uczelni polegające na zamianie etatów badawczo-dydaktycznych na dydaktyczne (ci ostatni nie są brani pod uwagę w procedurze parametryzacyjnej). Można też zejść z zatrudnieniem na etatach badawczych i badawczo-dydaktycznych (dokładniej: „prowadzących działalność naukową w danej dyscyplinie [...]" (art. 265 ust. 4 Ustawy z dnia 20 lipca 2018 r. Prawo o szkolnictwie wyższym) poniżej 12 osób i w ten sposób znika w tej uczelni dyscyplina naukowa, a z nią wstydliwa potencjalna kategoria „C” (plama na honorze uczelni). Dyscypliny naukowej nie ma (nie ma co oceniać i nie ma zagrożenia otrzymania kategorii „C”), a na atrakcyjny kierunek (co z tego, 
badaczy. Zwłaszcza tych na naukowym dorobku, do podejmowania zadań, których wykonanie jest rozłożone na wiele lat. Jak wycenić punktowo, przykładowo, tak ważny dla polskiej nauki i kultury, zainicjowany w 1935 roku i jeszcze nie doprowadzony do końca, Polski słownik biograficzny; latami wydawaną Bibliografię literatury polskiej „Nowy Korbut” czy opracowywany od 1949 roku Atlas polskich strojów ludowych? Przecież to są wydawnictwa pomnikowe o nieprzemijającej wartości. Pracowało (i pracuje) nad nimi wielu specjalistów. Ich wysiłek powinien być należycie doceniony.

Opłacalniejsze - i dla samego badacza, i dla instytucji go zatrudniającej - jest podejmowanie badań o krótszej perspektywie czasowej dojścia do wyniku. Liczy się zebranie jak największej liczby punktów.

Mój - i nie tylko mój - niepokój budzi wpychanie młodych, dopiero terminujących doktorantów, i tych starszych, habilitantów, w „wyścig szczurów”. Nie jest ważne, nad czym pracuję i ile czasu muszę temu poświęcić. Ważne staje się nagromadzenie jak największej liczby punktów. Praca nad jedną publikacją wymagającą wielu miesięcy jest mniej „opłacalna” od tej, która wymaga znacznie mniejszego nakładu czasu, a na dodatek, jeszcze przynosi więcej punktów. To jest zabójcze dla formowania przyszłego pokolenia badaczy, którzy przyjdą po nas, których czas aktywności naukowej powoli się kończy. Buchalteria naukowa zabija coś jeszcze - radość w uczestniczeniu w czymś ważnym: w dochodzeniu do prawdy i satysfakcję z wykonanego zadania.

Trafnie ten pseudomodel uprawiania, jak by powiedział Czesław Miłosz, ogrodu nauk podsumował Jacek Kubiak (2019: 3):

Parametryczna ocena pracy naukowców, polegająca na liczeniu punktów, niszczy naukę i deprawuje naukowców. Szczególnie młodych. System ten odcina nas od esencji naszego zajęcia, czyli od działania w celu zaspokojenia własnej ciekawości. Leonardo da Vinci, Galileusz, Kartezjusz, Darwin i zapewne Einstein w mgnieniu oka wyrzuciliby ten system do kosza. Ujrzeliby bowiem to, czego my nie widzimy lub staramy się nie dostrzegać: młodzi ludzie, którzy wzrastają w tym systemie, nie poznają etosu nauki, nie będą robić nauki dla zaspokojenia swej ciekawości, lecz będą walczyć o punkty! I będzie to walka coraz bardziej bezwzględna. Dowiedzą się, ba, już wiedzą, że ich przyszłość nie zależy od siły ich intelektu, wyobraźni, zasobu zgromadzonej wiedzy, umiejętności współpracy, ale od abstrakcyjnych punktów uzbieranych dla kariery. (wyróż. moje)

że prowadzony przez jednostkę uczelni, która nie poddała się ocenie) studenci garną się jak misie do miodu. Można to, jednak nieetyczne postępowanie zablokować. Można wprowadzić wymóg - dla studiów II ${ }^{0}$ i jednolitych studiów magisterskich (w obu profilach: ogólnoakademickim i praktycznym) - poddania się przeprowadzanej przez KEJN ocenie parametrycznej. 
Dziś cofamy się do fazy zbierackiej w nauce. Premiuje się tych, którzy nazbierają najwięcej punktów do koszyka (zob. kryteria oceny dorobku osób ubiegających się o stopień naukowy doktora habilitowanego zapisane w Rozporzq̨dzeniu Ministra Nauki i Szkolnictwa Wyższego z dnia 1 września 2011 roku w sprawie kryteriów oceny osiagnięć osoby ubiegajqcej się o nadanie stopnia doktora habilitowanego ${ }^{18}$. Takie podejście do zarządzania nauką daje szybkie, mozaikowe efekty. Z tym „modelem” radzą sobie (pozornie!), chyba jako jedyni NHS, psychologowie - zwłaszcza ci pracujący w zespołach międzynarodowych i prowadzący badania w laboratoriach. Ale tak prawdziwej nauki nie można uprawiać. Już dziś widzimy, że rocznie drukuje się tysiące - od strony warsztatowej wysoce poprawnych - artykułów z wynikami badań empirycznych, które trudno zmieścić w ramach nośnej poznawczo syntezy teoretycznej. Chciałoby się zapytać: A gdzie są te syntezy - nawet nie te wielkie?

Z kolei w klasycznej humanistyce liczą się jednak przede wszystkim monografie, będące nie tak rzadko efektem wieloletnich i żmudnych badań (na przykład kwerend archiwalnych). To one wzmacniają poznawczo uprawianą dyscyplinę naukową. Czy dostrzeżono tę osobliwość klasycznej humanistyki? Moim zdaniem: nie dostrzeżono. Co z tego, że podniesiono liczbę punktów za monografię. Tyle samo punktów (NHS, Poziom I: 100 pkt. zamiast 80 pkt.) - i za tę oryginalną, twórczą i obszerną oraz za tę naukowo mizerną, kilkuarkuszową i zasługującą, co najwyżej, na miano „syntezy

18 Zob. zwłaszcza: „§ 3. Kryteria oceny w zakresie osiągnięć naukowo-badawczych habilitanta obejmują:

1) w obszarze nauk humanistycznych — autorstwo lub współautorstwo publikacji naukowych w czasopismach znajdujących się w bazie Web of Science (WoS) lub na liście European Reference Index for the Humanities (ERIH);

2) w obszarze nauk społecznych - autorstwo lub współautorstwo publikacji naukowych w czasopismach znajdujących się w bazie Journal Citation Reports (JCR) lub na liście European Reference Index for the Humanities (ERIH), [...]”.

Także, szczególnie: „§ 4. Kryteria oceny w zakresie osiągnięć naukowo-badawczych habilitanta we wszystkich obszarach wiedzy obejmują: [...]

3) sumaryczny impact factor publikacji naukowych według listy Journal Citation Reports (JCR), zgodnie z rokiem opublikowania;

4) liczbę cytowań publikacji według bazy Web of Science (WoS);

5) indeks Hirscha opublikowanych publikacji według bazy Web of Science (WoS); [...]”. Chciałbym zauważyć nietrafność - zwłaszcza dla publikacji z obszaru humanistyki i części nauk społecznych - przywołania bazy WoS, a nie, przykładowo, bazy Google Scholar i bazy SCOPUS. Z kolei baza ERIH (czy jej nowsza wersja ERIH PLUS) jest tylko bazą rejestrową i nie powinna być używana w procedurach ewaluacyjnych. 
introligatorskiej”). Nie muszę dodawać, że sprzyja to różnym patologiom (zob. Brzeziński, 2018). Takim, mało wyrafinowanym, zabiegiem jest podzielenie jednej większej książki na dwie czy trzy mniejsze. I ze 100 pkt. mamy ich 300.

Moim zdaniem, trafna ocena działalności naukowej całych zespołów reprezentujących określoną dyscyplinę nauki i pojedynczych badaczy wymaga zmiany obowiązujących ustaw i rozporządzeń. Nie wystarczy łatanie dziur w przepisach, aby zlikwidować merytoryczne i prawne nonsensy. Myślę też, że przeliczanie na punkty dorobku naukowego nie daje trafnego wglądu w jego merytoryczny profil. Daje tylko powierzchowny obraz.

I jeszcze jedno. Tylko ocena peer review ma głęboki sens. Wskaźniki, takie jak IF czy sumIF, nie wnoszą istotnych informacji do merytorycznej oceny wniosków ${ }^{19}$. Z kolei indeks Hirscha tylko w bardzo ograniczonym zakresie może być stosowany - i to pomocniczo w procedurze peer review do oceny osiągnięć naukowych badaczy ${ }^{20}$. Gdyby recenzenci powołani w postępowaniach habilitacyjnych z obszaru NHS (a zwłaszcza klasycznej humanistyki) kierowali się zaleceniami ujętymi w Rozporzq̨dzeniu Ministra Nauki i Szkolnictwa Wyższego z dnia 1 września 2011 roku w sprawie kryteriów oceny osiagnięć osoby ubiegajq̨cej się o nadanie stopnia doktora habilitowanego (§ 4 - zob. przypis 18), to, być może, tylko nieliczne wnioski (na pewno z psychologii) mogłyby liczyć na pozytywną ocenę „osiągnięć naukowo-badawczych”. To kolejny przykład nieliczenia się z osobliwościami dyscyplin należących do klasycznej humanistyki.

$* * *$

Andrzej Wilczkowski zakończył swoje wspomnienia (przywołane w przypisie 1) górskie słowami, którymi - jak mi się zdaje - można zakończyć mój artykuł upominający się o „miejsce przy stole” dla nauk humanistycznych i społecznych (2002: 296-297):

19 Zob. jednoznaczne stanowisko w tej sprawie zajęte w Deklaracji San Francisco nt. Oceny Badań Naukowych DORA (DORA, 2013): „1. Nie należy stosować danych bibliometrycznych czasopism (journal-based metrics), takich jak Journal Impact Factors, jako zastępczej miary jakości poszczególnych artykułów naukowych, do oceniania wkładu konkretnych badaczy czy podejmowania decyzji o ich zatrudnieniu, promowaniu lub finansowaniu. [...]" (s. 503).

${ }^{20}$ Tak, przykładowo, postępuje Fundacja na rzecz Nauki Polskiej przy ocenie wniosków składanych przez badaczy w różnych konkursach. 
Jest w sali jadalnej w morskoocznym schronisku jeden stolik ustawiony pomiędzy dwoma oknami - w samym kącie sali. Pierwszy taternik, który rano wychodzi na śniadanie, wciska się właśnie w ten kąt. [...] Wieczorami, kiedy ostatni „passanci” opuszczą Morskie Oko, przy stoliku znowu zbiera się gromada. Toczą się dyskusje, snują opowieści. Piętrzą się stosy pudeł z jedzeniem, rosną baterie kubków po wrzątku wypełnionych rozprażonymi listkami herbacianymi.

Znajdą się i kufle po piwku. Wokół, w narzuconych kurtkach puchowych tkwią postacie na ogół prawie nieruchomo. Nie spostrzeżesz zbędnych gestów, niepotrzebnych ruchów. Czasem wybuchnie śmiech, czasem zapanuje chwila milczenia.

Koledzy, którzy przyjechaliście do Morskiego Oka jak do domu, wracając z Kordylierów, lub na krótko przed wyruszeniem w Himalaje. Jeżeli zobaczycie kiedyś starszego pana, chciwie zerkającego w stronę tego stołu - zróbcie mu miejsce. To może być któryś z chłopców z tamtych lat.

Przejdzie ćwierćwiecze, a i wam zdarzy się spoglądać w tamtą stronę, myśląc z melancholią, ale i z radością - że wasze miejsce ktoś zajął.

Bo tak być powinno.

\section{Literatura}

Antonowicz, D., Brzeziński, J.M. (2013). Doświadczenia parametryzacji jednostek naukowych z obszaru nauk humanistycznych i społecznych 2013 - z myślą o parametryzacji 2017. Nauka, 4, 51-85.

Brzeziński, J. (2016). Przeciwko depersonalizacji i nadmiernej standaryzacji procesu ewaluacji w nauce. Zagadnienia Naukoznawstwa, 1 (207), 123-133.

Brzeziński, J. (2018). Źródła nieetycznych zachowań badaczy i nauczycieli akademickich z dziedziny nauk społecznych. W: G. Króliczak, K. Łastowski, Ł. Przybylski, P. Przybysz, M. Urbański (red.), Filozof w krainie umysłów. Profesorowi Andrzejowi Klawiterowi w darze (s. 371-389). Poznań: Wydawnictwo Naukowe Wydziału Nauk Społecznych UAM.

Brzeziński, J.M. (2015). Czy uzasadniony jest postulat uwzględnienia specyfiki nauk humanistycznych i społecznych przy ocenie jednostek naukowych i badaczy? Między peer review a bibliometrią i naukometrią. Człowiek i Społeczeństwo, 39, 9-30.

Brzeziński J.M. (2017). O poprawianiu (ale też i o psuciu) systemu przeprowadzania awansów naukowych w Polsce w latach: 1990-2017. Nauka i Szkolnictwo Wyższe, 2 (50), 131-156.

DORA (2013). Deklaracja z San Francisco nt. Oceny Badań Naukowych (DORA): czy to początek końca dotychczasowej metody oceny parametrycznej? Nowotwory. Journal of Oncology, 63 (6), 501-504.

Kubiak, J. (2019). Walka o punkty zabija naukę. PAUza Akademicka, 460, 3.

Kulczycki, E. (2019). Procedury ewaluacji czasopism, współczynniki wpływu i listy czasopism. Seria Raportów Centrum Studiów nad Politykq Publicznq UAM. Raport VIII. Poznań: Centrum Studiów nad Polityką Publiczną UAM. 
Kwiek, M. (2020). O rosnącej roli prestiżowych publikacji. Życie Uniwersyteckie, 4 (320), $14-15$.

Kulczycki, E., Engels, T.C.E., Pölönen, J., Bruun, K., Dušková, M., Guns, R., ... i Zuccala, A. (2018). Publication patterns in the social sciences and humanities: evidence from eight European countries. Scientometrics. 116 (1), 463-486.

Wilczkowski, A. (1982/2002). Miejsce przy stole, wyd. 3. Łódź: Wydawnictwo Łódzkie.

Wilkin, J. (2013). Ocena parametryczna czasopism naukowych w Polsce - podstawy metodologiczne, znaczenie praktyczne, trudności realizacji i perspektywy. Nauka, 1, 45-54.

Wojtczak, K. (2016a). O stopniach naukowych w Polsce Ludowej. Część 1. Niższe stopnie naukowe. Studia Prawa Publicznego, 1 (13), 27-65.

Wojtczak, K. (2016b). W kwestii wyższego stopnia naukowego doktora w Polsce Ludowej. Studia Prawa Publicznego, 4 (16), 33-57.

Wojtczak, K. (2017a). Habilitacje w Polsce Ludowej. Część 1. Warunki i przebieg habitacji w prawie szkół wyższych. Studia Prawa Publicznego, 1 (17), 25-62.

Wojtczak, K. (2017b). Habilitacje w Polsce Ludowej. Część 2. Warunki i przebieg habilitacji w prawie o stopniach i tytułach naukowych. Studia Prawa Publicznego, 2 (18), 43-82.

Wróblewski, A.K. (2017). Nie wszystko, co się liczy, da się policzyć... Nauka, 1, 7-22.

\section{Akty prawne}

Ustawa z dnia 12 września 1990 r. o szkolnictwie wyższym. Dz. U. 1990, poz. 385;

Ustawa z dnia 12 września 1990 r. o tytule naukowym i stopniach naukowych. Dz. U. 1990, poz. 386.

Ustawa z dnia 12 stycznia 1991 r. o utworzeniu Komitetu Badań Naukowych. Dz. U. 1991, poz. 28.

Ustawa z dnia 30 kwietnia 2010 r. o instytutach badawczych (tekst jednolity z 28 czerwca 2019 r.) Dz. U. 2019, poz. 1350.

Ustawa z dnia 20 lipca 2018 r. Prawo o szkolnictwie wyższym. Dz. U. 2018, poz. 1668.

Rozporzq̨dzenie Ministra Nauki i Szkolnictwa Wyższego z dnia 1 września 2011 r. w sprawie kryteriów oceny osiagnięć osoby ubiegajq̨cej się o nadanie stopnia doktora habilitowanego. Dz. U. 2011, poz. 1165.

Rozporzqdzenie Ministra Nauki i Szkolnictwa Wyższego z dnia 22 lutego 2019 r. w sprawie ewaluacji jakości działalności naukowej. Dz. U. 2019, poz. 392. 